\title{
SEED HEALTH OF COMMON BEAN STORED AT CONSTANT MOISTURE AND TEMPERATURE
}

\author{
Fabiana Gonçalves Franciscoํㅜ Roberto Usberti ${ }^{2 *}$ \\ ${ }^{1}$ UNICAMP/FEAGRI - Programa de Pós-Graduação em Engenharia Agrícola - C.P. 6011, 13083-875, Campinas, \\ SP - Brasil. \\ ${ }^{2}$ Coordenadoria de Defesa Agropecuária, SAA/SP. C. P. 960, 13073-001- Campinas, SP - Brasil. \\ *Corresponding author<usberti@cati.sp.gov.br>
}

\begin{abstract}
Fungal incidence in stored common bean (Phaseolus vulgaris L.) is the main concern in order to preserve seed health and viability. The main aim of this study was to analyse these quality parameters in hermetically stored seeds at 10.2, 13.1, 16.2, 18.5\% moisture content (MC) and 25, 30, 35, $40^{\circ} \mathrm{C}$, through seed germination and health tests. Water activity recorded at 10.2 and 18.5\% MC were 0.448 and 0.700 , respectively. Low seed moisture content reduced Alternaria spp. incidence at 25$30^{\circ} \mathrm{C}$. Highest incidence of Fusarium spp. (7.5\%) occurred at $16.2 \% \mathrm{MC}$ and $35-40^{\circ} \mathrm{C}$. Highest incidences of Rhizoctonia spp. (8-10\%) were recorded at $16.2-18.5 \% \mathrm{MC}$ and $30-40^{\circ} \mathrm{C}$. Penicillium spp. and Aspergillus spp. were predominant throughout the experiment and the highest incidences (80-100\%; $20-30 \%$, respectively) were scored at $18.5 \% \mathrm{MC}$ and $30-35^{\circ} \mathrm{C}$ and $13.1-18.5 \% \mathrm{MC}$ at $35^{\circ} \mathrm{C}$, respectively. The higher the seed MC the higher the fungi incidence while lower seed MC decreased the incidences by $25 \%$. Storage conditions below $30^{\circ} \mathrm{C}$ and $13.0 \% \mathrm{MC}$ appear suitable to preserve common bean seed in relation to viability and health, up to a 8-month period.
\end{abstract}

Key words: seed healthiness, hermetic storage, fungal incidences

\section{SANIDADE DE SEMENTES DE FEIJÃO ARMAZENADASA UMIDADE E TEMPERATURACONSTANTES}

\begin{abstract}
RESUMO: A incidência de fungos em sementes de feijão (Phaseolus vulgaris L.) é a preocupação principal de cientistas e tecnologistas de sementes visando preservar a sua sanidade e viabilidade. $\mathrm{O}$ objetivo deste estudo foi analisar esses parâmetros de qualidade em sementes hermeticamente armazenadas com graus de umidade de 10,2, 13,1, 16,2 e 18,5\% a $25,30,35,40^{\circ} \mathrm{C}$, através de testes de germinação e de sanidade. Os valores de atividade de água obtidos para graus de umidade de 10,2 e 18,5\% foram de 0,448 e 0,700 . Baixos graus de umidade reduziram a incidência de Alternaria spp. a $25-30^{\circ} \mathrm{C}$. A maior incidência de Fusarium spp. (7,5\%) ocorreu com grau de umidade de $16,2 \%$ a $35-40^{\circ} \mathrm{C}$. As maiores incidências de Rhizoctonia spp. (8-10\%) foram registradas para graus de umidade de 16,2 e $18,5 \%$ a $30-40^{\circ} \mathrm{C}$. Os fungos Penicillium spp. e Aspergillus spp. foram predominantes durante todo o experimento, sendo que as maiores incidências (80-100\%; 20-30\%) foram registradas para 18,5\% de umidade a 30-35 $\mathrm{C}$ e 13,1-18,5\% de umidade a $35^{\circ} \mathrm{C}$, respectivamente. Quanto maior o grau de umidade da semente maior foi a incidência de fungos, enquanto que os valores mais baixos de umidade reduziram essas incidências a $25 \%$. Temperaturas de armazenamento abaixo de $30^{\circ} \mathrm{C}$ e graus de umidades inferiores a $13,0 \%$ parecem ser as condições adequadas para preservar a viabilidade e a sanidade de sementes de feijão por até 8 meses. Palavras-chave: patologia de sementes, armazenamento hermético, incidência de fungos
\end{abstract}

\section{INTRODUCTION}

Brazil is one of the largest common bean producers in the world, therefore requiring high technology for the maintenance of seed quality parameters as to physical purity, germination and health percentages. Several factors may affect common bean seed conservation, mainly including seed health, moisture content (MC), temperature (T), relative humidity $(\mathrm{RH})$ and the action of fungi and insects. High $\mathrm{T}$ and $\mathrm{MC}$ accelerate degenerative processes in biological systems, causing gradual, irreversible and accumulative losses in vigour and viability (Delouche \& Baskin, 1973). Seeds present a lower respiration rate during storage than external and internal fungi (Lazzari, 1993).

Seeds are the vehicles for transmission of several fungi and frequently introduce new pathogens in exempt areas, so that the integration between seed health and germination tests is recommended to control seed transmitted diseases (Zaumeyer \& Thomas, 1957; Singh \& Mathur, 1974; Bolkan et al., 1976.; Neergaard, 1977). However, most of the research has 
emphasised seed health in open-stored common bean, not taking into account controlled environments.

Field fungi activity is delayed during storage at low seed MC since they require $\geq 90 \%$ air $\mathrm{RH}$ for growth (Lazzari, 1993). Fast development and high aggressiveness of these pathogens could kill the seed after sowing due to the action of powerful enzymes and toxins. On the other hand, storage fungi usually develop in seeds in equilibrium at 65-90\% air RH (around 12-13\% MC) (Loewer et al., 1994). A decrease in field fungi and an increase in storage fungi populations occur after harvest, in an ecological succession. The main objective of this research was to analyse seed germination and fungi incidences in common bean under controlled storage conditions to define an optimum $\mathrm{MC}$, storage period and $\mathrm{T}$ required to maintain high seed health and viability.

\section{MATERIALAND METHODS}

Seven $\mathrm{kg}$ of common bean seeds cv. IAC-Carioca ETE, were harvested in the 1998-99 season, in Campinas, São Paulo State, Brazil. Seed MC was adjusted at $25^{\circ} \mathrm{C}$ to $10.2,13.1,16.2$ and $18.5 \% \mathrm{MC}$, from an initial value of $15.1 \%$, either by rehydration over water in a closed plastic box or by dehydration over silica gel, aiming to avoid possible damage to the seeds caused by fast dehydration / rehydration. Seeds were sealed in laminated aluminium-foil packets (polyester structure / aluminium / low-density polyethylene, with a total thickness of $120 \mathrm{~mm}$ ) and stored in incubators maintained at $25,30,35$ and $40^{\circ} \mathrm{C}\left( \pm 0.5^{\circ} \mathrm{C}\right)$.

Seed MC (fresh weight basis) was determined in three $5 \mathrm{~g}$ ground seed samples at $130-133^{\circ} \mathrm{C}$ for 2 h (ISTA, 2004). Water activity ( $\left.A_{w}\right)$ was determined using three seed samples for each MC in a hygrometer using the dew point technique, at $25^{\circ} \mathrm{C} \pm 0.3( \pm$ $\left.0.01 \mathrm{~A}_{\mathrm{w}}\right)$. Germination tests were performed at $25^{\circ} \mathrm{C}$ using $4 \times 50$ seed replicates for each MC / temperature / sampling date combination, placed in rolled paper towels moistened with deionised water, with initial and final seedling counts recorded at the 5th and 9th days, respectively (ISTA, 2004).

Fungi incidences were determined by the blotter test (Neergaard, 1977), using 200 seeds $(20 \times 10$ replicates) for each $\mathrm{MC}$ / temperature / sampling date combination, incubated at $20^{\circ} \mathrm{C}$ during seven days under 12-h alternating cycles of NUV-light (320-400 nm) and darkness, followed by evaluation under a stereoscopic microscope. Seeds were placed in plastic Petri dishes (9 cm diameter), with three filter papers moistened with sterilised water and previously decontaminated in a 1\% sodium hypochlorite solution for 5 minutes (Berjark, 1984; Usberti \& Amaral, 1999). Seed fungi incidences were estimated through observations of their structures (Barnett \& Hunter, 1972).

Sampling intervals for seed health tests were quite variable due to the different levels of deterioration in relation to MC and storage T (Table 1). Preliminary results revealed no significant differences among initial and sampling time MCs. Fungi incidences for each combination among storage period, $\mathrm{T}$ and $\mathrm{MC}$ were compared using Fisher's LSD test $(p<0.05)$. Prior to statistical analyses, germination percentages and fungi incidences were transformed into arcsine $\sqrt{ } \% / 100$ and $\sqrt{ }(x+1)$, respectively.

\section{RESULTS AND DISCUSSION}

\section{Water activity}

$A_{w}$ is the quotient of seed vapour pressure over pure water vapour pressure at the same temperature and is an important parameter in storage studies since it is closely related to rate and intensity of common bean seed deterioration (Sartori, 1996). The $\mathrm{A}_{\mathrm{w}}$ values recorded on each seed MC (45-70\% RH) were 0.448 ,

Table 1 - Sampling intervals (days) for seed health tests on common bean seeds stored at 25, 30, 35, $40^{\circ} \mathrm{C}$ and $10.2,13.1,16.2$, $18.5 \%$ moisture content (MC).

\begin{tabular}{|c|c|c|c|c|c|c|c|c|c|c|c|c|c|c|c|}
\hline \multicolumn{4}{|c|}{$10.2 \% \mathrm{MC}$} & \multicolumn{4}{|c|}{$13.1 \% \mathrm{MC}$} & \multicolumn{4}{|c|}{$16.2 \% \mathrm{MC}$} & \multicolumn{4}{|c|}{$18.5 \% \mathrm{MC}$} \\
\hline $25^{\circ} \mathrm{C}$ & $30^{\circ} \mathrm{C}$ & $35^{\circ} \mathrm{C}$ & $40^{\circ} \mathrm{C}$ & $25^{\circ} \mathrm{C}$ & $30^{\circ} \mathrm{C}$ & $35^{\circ} \mathrm{C}$ & $40^{\circ} \mathrm{C}$ & $25^{\circ} \mathrm{C}$ & $30^{\circ} \mathrm{C}$ & $35^{\circ} \mathrm{C}$ & $40^{\circ} \mathrm{C}$ & $25^{\circ} \mathrm{C}$ & $30^{\circ} \mathrm{C}$ & $35^{\circ} \mathrm{C}$ & $40^{\circ} \mathrm{C}$ \\
\hline 0 & 0 & 0 & 0 & 0 & 0 & 0 & 0 & 0 & 0 & 0 & 0 & 0 & 0 & 0 & 0 \\
\hline 189 & 189 & 118 & 118 & 150 & 150 & 189 & 109 & 130 & 15 & 4 & 3 & 24 & 15 & 4 & 2 \\
\hline \multirow[t]{7}{*}{242} & 242 & 200 & 200 & 242 & 200 & 214 & 116 & 200 & 24 & 7 & 7 & 104 & 23 & 7 & 4 \\
\hline & & 207 & 205 & & 242 & & 123 & 214 & 60 & 11 & 11 & 109 & 49 & 11 & 7 \\
\hline & & 210 & 210 & & & & 130 & 259 & 100 & 23 & 18 & 116 & 60 & 21 & 10 \\
\hline & & 214 & 214 & & & & 132 & & 109 & 56 & 22 & 123 & 63 & 29 & 18 \\
\hline & & 230 & 216 & & & & 137 & & 130 & 60 & 25 & 130 & 70 & 39 & 22 \\
\hline & & & & & & & 140 & & & 63 & 29 & 140 & & 43 & 29 \\
\hline & & & & & & & & & & & 32 & & & & \\
\hline
\end{tabular}


$0.571,0.674$ and 0.700 for $10.2,13.1,16.2$ and $18.5 \%$ MC, respectively.

\section{Statistical analyses}

Statistical analyses of fungi incidences on common bean seeds are presented in Table 2, for each com-

Aspergillus spp.
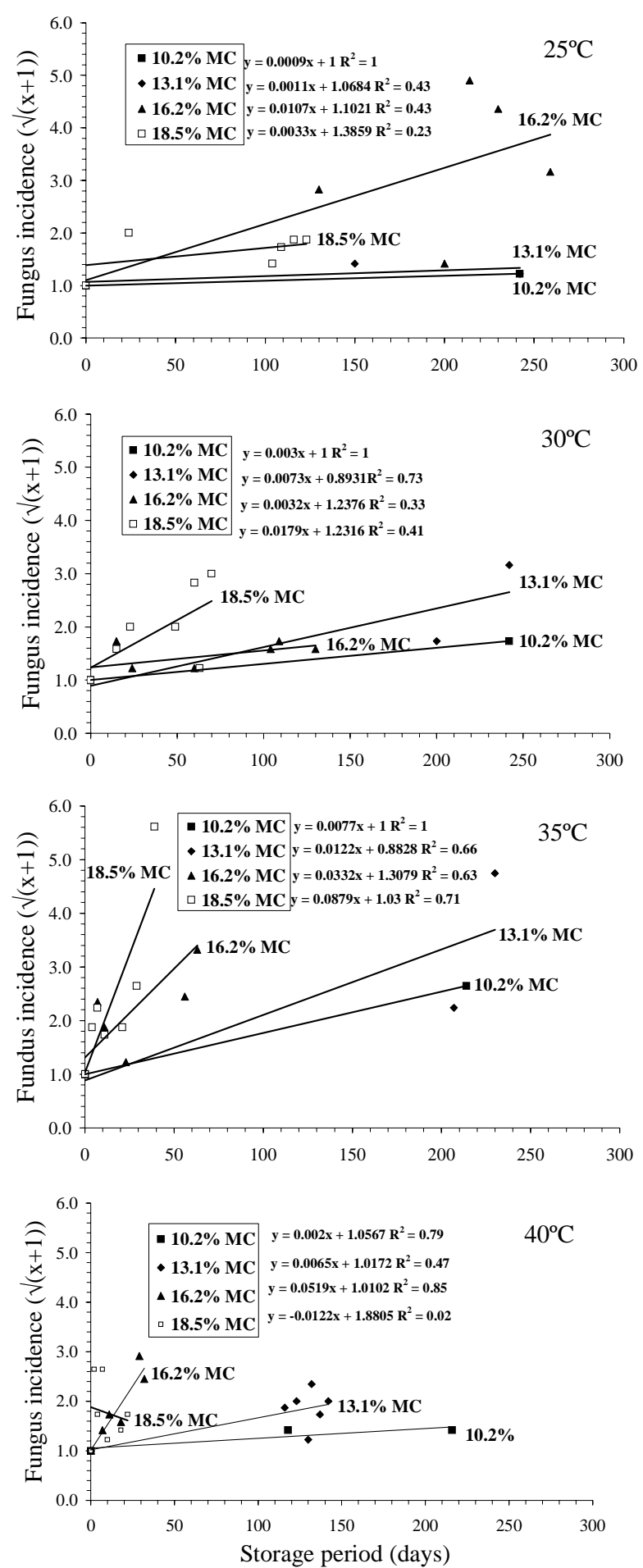

bination of storage period, T and MC. No statistical interaction were recorded among fungi incidences, storage T and seed MC. Penicillium spp. and Aspergillus spp. revealed the highest incidences among fungi throughout the experiment (Figures 1 and 2). Regression lines of fungi incidences were observed in shorter

\section{Penicillium spp.}
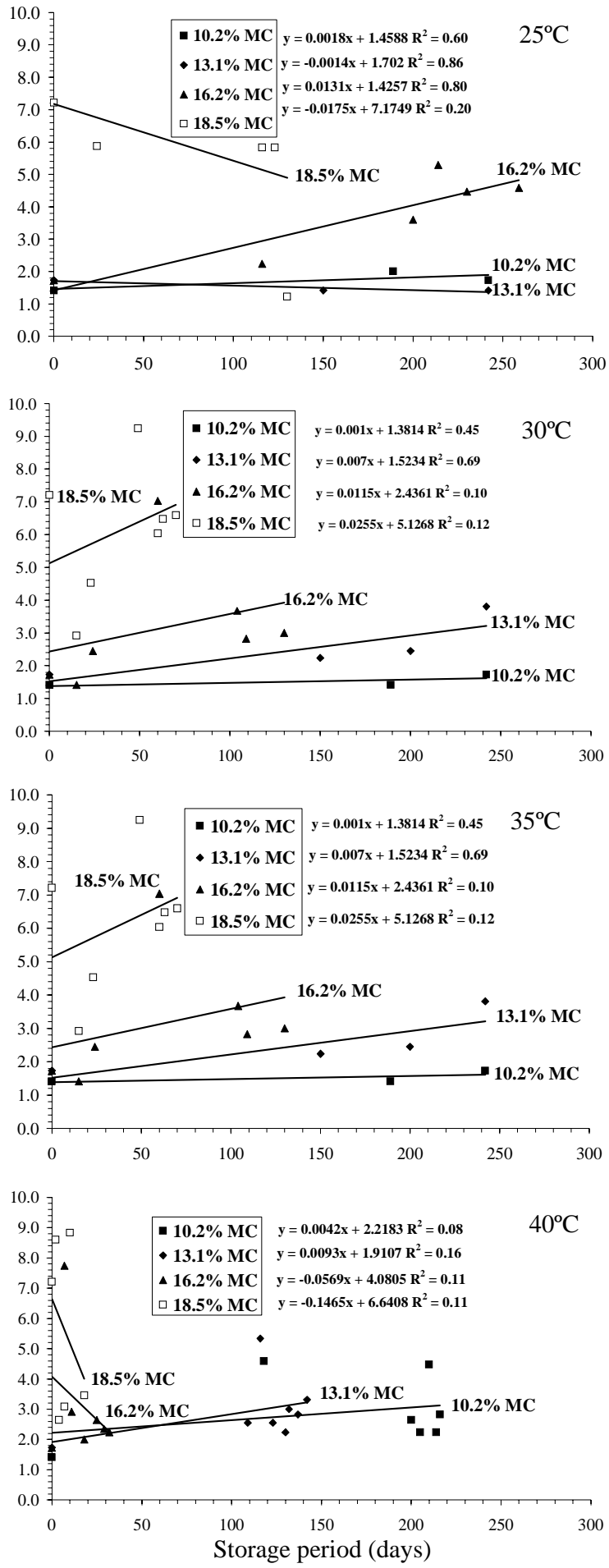

Figure 1 - Regression lines of storage fungi (Aspergillus spp. and Penicillium spp.) incidences $(\sqrt{ }(\mathrm{x}+1))$ in common bean seeds stored at $25,30,35,40^{\circ} \mathrm{C}$ and $10.2,13.1,16.2,18.5 \%$ moisture content (MC). 
storage periods according to increases on seed MC and storage $\mathrm{T}$.

The determination coefficients estimated for storage fungi incidences (Figure 1), ranging from 0.08 to 1 , revealed a decreasing tendency, according to increases on MC and storage T. However, the values recorded for field fungi incidences (Figure 2) were quite variable, ranging from zero to 1 , without showing a specific tendency.

\section{Storage fungi incidences}

Penicillium spp. and Aspergillus spp. are the main storage fungi in common bean and usually invade the seeds during and after maturation, causing damage as soon as they find appropriate conditions.
The primary coloniser is Aspergillus spp., which subsequently allows the development of Penicillium spp. (Faiad et al., 1996). Penicillium spp. and Aspergillus spp. incidences scored in common bean seeds stored at $25,30,35,40^{\circ} \mathrm{C}$ and $10.2,13.1,16.2,18.5 \% \mathrm{MC}$ are presented in Figure 1.

Aspergillus spp. - Fungal incidences higher than $20 \%$ were recorded at different MC / temperature combinations, mainly in early storage periods and 16.2-18.5\% MC, except at 10.2-13.1\% MC / $35-40^{\circ} \mathrm{C}$, when these values were scored until 200-230-day storage periods. Regardless of T, 10.2-13.1\% seed MC reduced fungal invasion until the 214-day storage when values around $6-8 \%$ were registered at $35^{\circ} \mathrm{C}$; however
Alternaria spp.
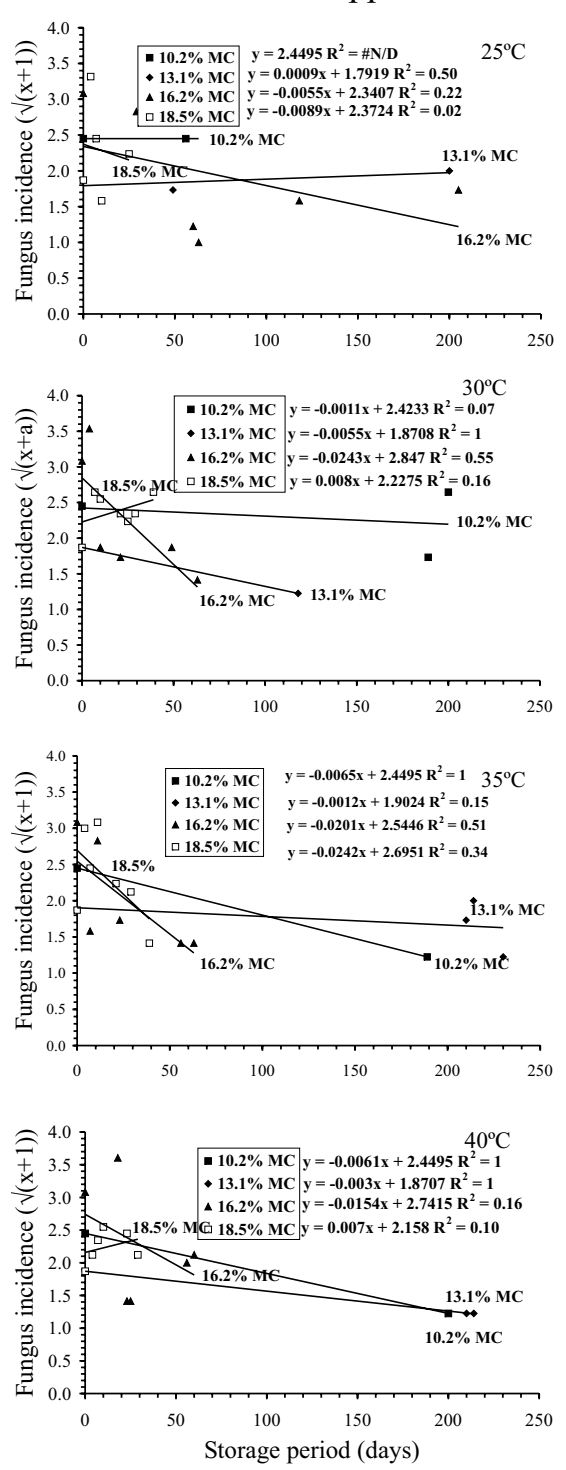

Fusarium spp.
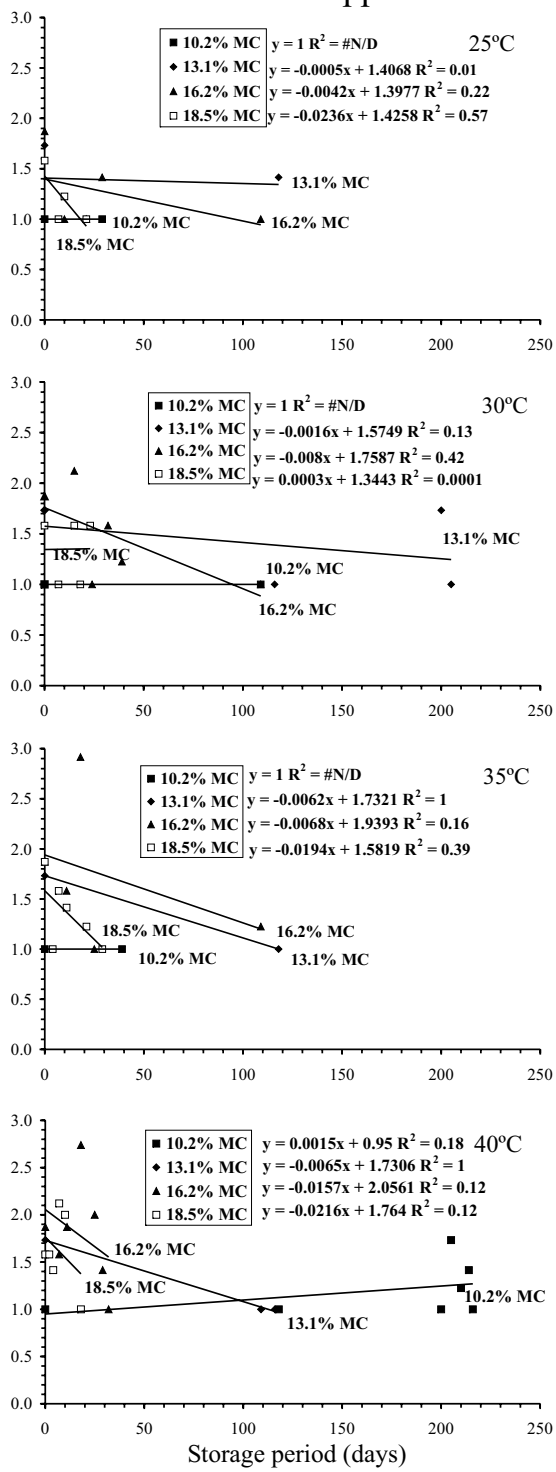

Rhizoctonia spp.
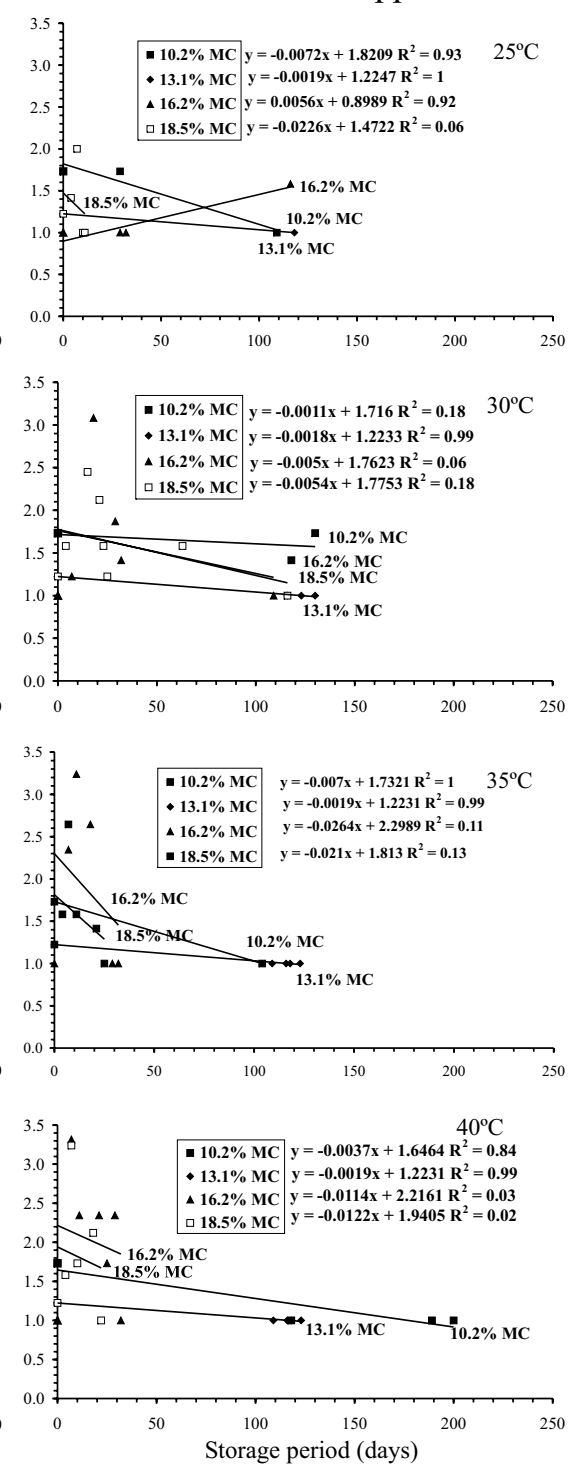

Figure 2 - Regression lines of field fungi (Alternaria spp., Fusarium spp. and Rhizoctonia spp.) incidences $(\sqrt{ }(\mathrm{X}+1)$ ) in common bean seeds stored at $25,30,35,40^{\circ} \mathrm{C}$ and $10.2,13.1,16.2,18.5 \%$ moisture content (MC). 
they increased by about $20 \%$ at $40^{\circ} \mathrm{C}$. Highest and earliest values were recorded at 16.2-18.5\% MC / 35$40^{\circ} \mathrm{C}$, respectively.

The presence of Aspergillus spp. in bean seeds was reported by Christensen (1972); Faiad et al. (1996) and Sinha et al. (1999); however, its occurrence was always associated with the presence of Penicillium spp. (Bolkan et al., 1976; Dhingra \& Sinclair, 1978). A high incidence of Aspergillus spp. (77\%) was detected in bean seeds during 24-month open storage conditions at $85-95 \%$ RH (Hernandez et al., 1994).

Penicillium spp. - Penicillium spp. had the highest incidences in common bean seeds, mainly at $18.5 \% \mathrm{MC}$ and $30-40^{\circ} \mathrm{C}(80-100 \%)$ while still higher values (around $60 \%$ ) were recorded at $25^{\circ} \mathrm{C}$ and 16.2 $18.5 \% \mathrm{MC}$. The higher the storage $\mathrm{T}$, the higher the fungus invasion during early storage periods. Lowest seed MC (10.2-13.1\%) reduced fungus incidences; however, at $30-35^{\circ} \mathrm{C}$, the values reached $10 \%$, while at $40^{\circ} \mathrm{C}$ some values were higher than $20 \%$. The best $\mathrm{T}$ range for fungus invasion was $30-35^{\circ} \mathrm{C}$ and $\mathrm{MC}$ higher than $16 \%$.

Highest incidences of Penicillium spp. were observed at $18.5 \% \mathrm{MC}$ at all T, while Aspergillus spp. contamination was only pronounced at $35^{\circ} \mathrm{C}$; so, the higher the seed MC, the higher the fungal incidences at early storage periods. Additional high $\mathrm{T}$ effects on fungi incidences could also be noted. Penicillium spp. and Aspergillus spp. presented the highest incidences in common bean seeds during hermetic storage. These results agree with Terveit (1945); Wilcox et al. (1974); Bolkan et al. (1976); Dhingra \& Sinclair (1978) and Hernandez et al. (1994).

Field fungi incidences - The most common field fungi detected in fresh bean seeds were Alternaria spp. and Fusarium spp. (Figure 2), which require seed $\mathrm{MC}$ in equilibrium to $90 \% \mathrm{RH}$ for growing and cause great impacts in crop yields (Abawi et al., 1977; Pieczarka \& Abawi, 1978; Sinha et al., 1999). Field fungi incidences remained below $12 \%$ throughout the experiment and lowest MC / T combinations (10.2-13.1\% and $25-30^{\circ} \mathrm{C}$ ) reduced the values below 6\% (Figure 2). Highest incidences of Alternaria spp. (8-12\%) were observed at $16.2-18.5 \% \mathrm{MC}$, however low MC were effective in restraining them. The higher $\mathrm{T}$, the greater the fungus incidence. On the other hand, Fusarium spp. occurred mainly at $16.2 \% \mathrm{MC}$ and $35-40^{\circ} \mathrm{C}$ and remained below than $3.5 \%$ at $25-30^{\circ} \mathrm{C}$. Rhizoctonia spp. highest incidence (8-10\%) was detected at $18.5 \% \mathrm{MC}$ and 30 $40^{\circ} \mathrm{C}$, however at $25^{\circ} \mathrm{C}$ the fungus occurrence was reduced. Field and storage fungi incidences were clearly reduced for the lowest MC $(10.2 \%, 13.1 \%)$ at 25 - $30^{\circ} \mathrm{C}$, with values remaining below 5 and $10 \%$, respectively (Figures 1 and 2).

\section{Seed germination}

Increases in $\mathrm{MC}$ reduced seed viability and this effect was more pronounced for highest seed MC (16.2, 18.5\%), unrelated to storage $\mathrm{T}$ (Figure 3). The
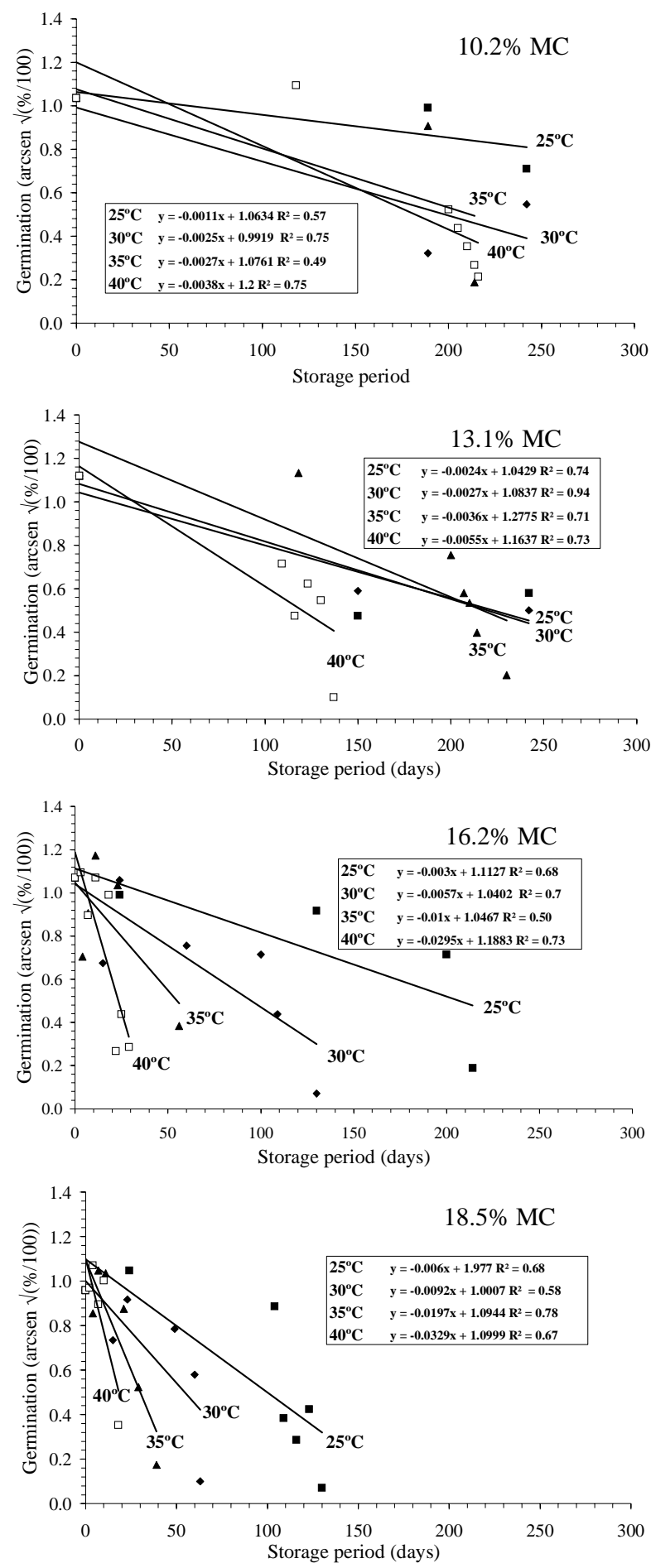

Figure 3 - Regression lines of standard germination (arcsine $\sqrt{ }(\% / 100))$ of common bean seeds stored at 25,30 $35,40^{\circ} \mathrm{C}$ and $10.2,13.1,16.2,18.5 \%$ moisture content. 
determination coefficients calculated for germination percentages were quite high, ranging from 0.49 to 0.94 , without showing a specific tendency according to MC and storage $\mathrm{T}$.

Some germination percentage reductions observed throughout the storage period might be influenced by previous high incidences of Penicillium spp. (60.5\% at 130 -day; $36.5 \%$ at 132-day) (Figure 1). Moreover, some early high incidences of Aspergillus spp. at 40 to 60-day storage could play an additional role in the deterioration process.

Similar results were reported by Chisholm \& Coates (1997), evaluating germination percentages and fungi incidences in three leguminous seeds during storage with subsequent germination reduction and increase in fungi incidences mainly at $28^{\circ} \mathrm{C}$. Stored beans (10.3$14.2 \% \mathrm{MC}$ at $30^{\circ} \mathrm{C}$ ) with high initial seed germination percentage and MC around $11.5 \%$ might maintain viability for eight months (Aguirre \& Peske, 1991). Sanhewe \& Ellis (1996) have also reported that bean seed quality was higher at cold temperatures during development and maturation.

\section{CONCLUSIONS}

Storage conditions with moisture content and temperature lower than $13.1 \%$ and $30^{\circ} \mathrm{C}$, respectively, appear to be adequate for maintenance of seed viability and healthiness up to 8-months storage. Such storage conditions, which might be easily reached by seed sun drying and open storage, suggest a closing remark as to potential benefits and offer seed producers with a strategy for maintaining seed viability.

\section{ACKNOWLEDGEMENTS}

To CNPq for the grant of Fabiana Gonçalves Francisco as well as to the Packaging Technology Center, Institute of Food Technology, Campinas, Brazil for providing the facilities for packaging the seeds and detecting equilibrium relative humidities.

\section{REFERENCES}

ABAWI, G.S.; CROSIER, D.C.; COBB, A.C. Pod-flecking of snap beans caused by Alternaria alternata. Plant Disease Reporter, v.61, p.901-905, 1977.

AGUIRRE, R.; PESKE, S.T. Seed moisture content required for short-term hermetic storage of beans. Seed Science \& Technology, v.19, p.117-122, 1991.

BARNETT, H.L.; HUNTER, B.B. Illustrated genera of imperfect fungi. 3 ed. Minneapolis, Burgess, 1972. 241p.

BERJARK, P. Report of the Seed Storage Committee-Working Group on the effects of storage fungi on seed viability. Seed Science \& Technology, v.12, p.233-253, 1984.
BOLKAN, H.A.; SILVA, A.R.; CUPERTINO, F.P. Fungi associated with soybean and bean seeds and their control in Central Brazil. Plant Disease Reporter, v.60, p.545-548, 1976.

CHISHOLM, F.V.; COATES, B.P.L. Fungi associated with seeds of three legume species in Jamaica and seed germination at harvest and after storage. Tropical Agriculture, v.74, p.121-127, 1997.

CHRISTENSEN, C.M. Microflora and seed deterioration. In: Roberts, E.H. (Ed.) Viability of seeds. London: Chapman \& Hall, 1972. p.59-93.

DELOUCHE, J.C.; BASKIN, C.C. Accelerated ageing techniques for predicting the relative storability of seeds lots. Seed Science \& Technology, v.1, p.427-552, 1973.

DHINGRA, O.D.; SINCLAIR, J.B. Biology and pathology of Macrophomina phaseolina. Viçosa: UFV, 1978. 166p.

FAIAD, M.G.R.; WETZEL, M.M.V.S.; SALOMÃO, A.N.; CUNHA, R. Evaluation of fungi in seed germoplasm before long term storage. Seed Science \& Technology, v.24, p.505-511, 1996.

HERNANDEZ, E.; FONT, A.; HERNANDEZ, M. Preservation of common beans in different containers and storage conditions. Plant Genetic Resources Newsletter, v.99, p.34-35, 1994.

INTERNATIONAL SEED TESTING ASSOCIATION - ISTA. International rules for seed testing. Bassersdorf: ISTA, 2004. 410p.

LAZZARI, F.A. Umidade, fungos e micotoxinas na qualidade de sementes, grãos e rações. Curitiba: Edição do autor, 1993. $146 \mathrm{p}$.

LOEWER, O.J.; BRIDGES, T.C.; BUCKLIN, R.A. Principles of drying. In: On-farm drying and storage systems. St. Joseph: American Society of Agricultural Engineers, 1994. p.27-71.

NEERGAARD, P. Seed pathology. New York: MacMillan, 1977. p.309-319.

PIECZARKA, D.J.; ABAWI, G.S. Effects of interaction Fusarium, Pythium and Rhizoctonia on severity of bean root rot. Phytopathology, v.68, p.403-409, 1978.

SANHEWE, A.J.; ELLIS, R.H. Seed development and maturation in Phaseolus vulgaris L. post-harvest longevity in air-dry storage. Journal of Experimental Botany, v.47, p.959-965, 1996.

SARTORI, M.R. Armazenamento. In: ARAÚJO, R.S.; RAVA, C.A. Cultura do feijoeiro comum no Brasil. Piracicaba: POTAFOS, 1996. p.543-560.

SINGH, D.; MATHUR, S.B. Sclerotiorum rolfsii in seed of bean from Uganda. Seed Science \& Technology, v.2, p.481-483, 1974.

SINHA, A.; SINGH, S.K.; QAISAR, J. Seed mycoflora of French bean and its control by means of fungicides. Tropenlandwirt, v.11, p.59-67, 1999.

TERVEIT, I.W. The influence of fungi on storage, on seed viability and seedling vigour of soybeans. Phytopathology, v.35, p.315, 1945.

USBERTI, R.; AMARAL, H.M. Fungicide dressing timing, seed size, seed origin and fungal incidence effects on groundnut (Arachis hypogaea L.) storability. Seed Science \& Technology, v.27, p.699-706, 1999.

WILCOX, J.R.; LAVIOLETTE, F.A.; ATHOW, K.L. Deterioration of soybean seed quality associated with delayed harvest. Plant Disease Reporter, v.58, p.130-133, 1974.

ZAUMEYER, W.S.; THOMAS, H.R. A monographic study of bean diseases and methods for their control. Washington, D.C.: USDA, 1957. 255p. (USDA Technical Bulletin, 868).

Received May 29, 2006

Accepted August 25, 2008 